\title{
17- Hayru’l-Buldan (Oş) Risalesi (çeviri yazı, ses bilgisi, şekil bilgisi)
}

\section{Recep YÜRÜMEZ ${ }^{1}$ \\ Ünal ALDEMIR²}

APA: Yürümez, R. \& Aldemir, Ü. (2022). Hayru'l-Buldan (Oş) Risalesi (çeviri yazı, ses bilgisi, şekil bilgisi). RumeliDE Dil ve Edebiyat Araştırmalar Dergisi, (26), 300-321. DOI: 10.29000/rumelide.1073919.

\section{$\ddot{O} \mathbf{z}$}

Türk İslam edebiyatında, geniş yazım alanı ve pek çok örneğiyle karşımıza çıkan fazilet-nâmeler genel olarak şehirlerin faziletlerini anlatan eserlerdir. Bu eserler, İslam medeniyeti için önemli olan şehirlerle ilgili menkıbeleri barındırmaktadır. Bu tür eserlerin Çağatayca yazılmış örneklerinden olan Hayru'l-Buldan Risalesi (Oş Risalesi) de Kırgızistan'ın güneybatısında bulunan ve günümüzde ülkenin ikinci büyük şehri olan Oş şehrinin faziletlerini anlatmaktadır. Oş şehri kadim bir medeniyet merkezi olmasının yanı sıra Doğu Türkistan ile Batı Türkistan arasında geçiş noktası olması ve Fergana Vadisi’nin doğuda başlangıç noktası olması hasebiyle coğrafi olarak da önemlidir. Çağatayca dönemine ait bir eser olan Hayru'l-Buldan Risalesi (Oş Risalesi) 26 varaktır ve her sayfada 6 satır bulunmaktadır. Eser, 12.5x7.5 cm çapındadır. Eserin yazarı Molla Ömer (Omar) Uzak’tır ancak ne zaman yazıldığı ile ilgili metinde herhangi bir bilgi bulunmamaktadır. Söz konusu çalışmamızda eserin çeviri yazısı yapılmış ve eser, ses ve şekil yönüyle incelenmiştir. Bu yolla eserdeki dil hususiyetleri ortaya konmaya çalışılmış Türk lehçelerine de ışık tutacak bazı dil özellikleri üzerinde de özellikle durulmuştur. Metin içerik olarak incelendiğinde ise Oş’un dini açıdan önemini vurgulamak için birçok peygamberden nakillere yer verildiği hatta Hz. Peygamber'den hadis olarak da şehir ile ilgili nakillerde bulunulduğu görülmektedir. Bu çalışma ile el yazması, öncelikle Çağatayca üzerine çalışmalar yapan araştırmacılar olmak üzere Türk dili ve tarihi üzerine çalışmalar yapan/yapacak tüm araştırmacıların istifadesine sunulmuştur.

Anahtar kelimeler: Hayru’l- Buldan (Oş Risalesi), Ses Bilgisi, Şekil Bilgisi, Çağatayca, Oş

\section{Hayru'l-Buldan (Osh) Tractate (translation writing, phonetics, morphology)}

\begin{abstract}
Fazilet-nâmes, which appear in Turkish-Islamic literature with their wide writing area and many examples, are generally works that describe the virtues of cities. These works contain legends about cities that are important for Islamic civilization. Hayru'l-Buldan Tractate (Osh Tractate), which is one of the examples of such works written in Chagatai, also describes the virtues of the city of Osh, which is located in the southwest of Kyrgyzstan and is the second largest city in the country today. In addition to being an ancient civilization center, Osh is also geographically important because it is a transition point between East Turkestan and West Turkistan and the Fergana Valley is the starting point in the east. Hayru'l-Buldan (Osh) Tractate, which is a work belonging to the Chagatai period, has 26 sheets and 6 lines on each page. The work is 12.5x7.5 cm in diameter. The author of the work

Dr. Kırgızistan-Türkiye Manas Üniversitesi Yabancı Diller Yüksekokulu (Bişkek, Kırgızistan), recep.yurumez@manas.edu.kg, ORCID ID: 0000-0002-8818-7695 [Araştırma makalesi, Makale kayıt tarihi: 01.12.2021kabul tarihi: 20.02.2022; DOI: 10.29000/rumelide.1073919]

Öğr. Gör. Dr., Recep Tayyip Erdoğan Üniversitesi, Eğitim Fakültesi (Rize, Türkiye), unal.aldemir@erdogan.edu.tr, ORCIDD ID: 0000-0002-2660-4414

RumeliDE Dil ve Edebiyat Araşttrmaları Dergisi Osmanağa Mahallesi, Mürver Çiçeği Sokak, No:14/8 Kadıköy - ÍSTANBUL / TÜRKIYE 34714 e-posta: editor@rumelide.com tel: +90 $5057958124,+902167730616$

Address

RumeliDE Journal of Language and Literature Studies

Osmanağa Mahallesi, Mürver Çiçeği Sokak, No:14/8

Kadıköy - ISTANBUL / TURKEY 34714

e-mail: editor@rumelide.com,

phone: +90 505 7958124, +90 2167730616
\end{abstract}


is Molla Omer (Omar) Uzak, however, there is no information in the text about when it was written. In our study, the translation of the work was made and the work was examined in terms of sound and form. Thus the language features in the work have been tried to be revealed, and some language features that will shed light on the Turkish dialects have been especially emphasized. When the text is examined in terms of content, it is clear that there are narrations from many prophets in order to emphasize the religious importance of Osh, and even there are narrations about the city as hadiths from the Prophet Muhammad. With this study, the manuscript has been presented to the benefit of all researchers who work/will work on Turkish language and history, primarily those who work on Chagatai.

Keywords: Hayru'l- Buldan (Osh Tractate), Phonology, Morphology, Chagatai, Osh

\section{Giriş}

Türk İslam edebî geleneğinde şehirler hakkındaki menkıbelerin anlatıldığı pek çok eser mevcuttur ve bunlardan birisi de şehirlerin faziletlerinin anlatıldığı fazilet-nâmelerdir. Fazilet-nâmeler öbürleri kadar tanınmamakla birlikte yazım alanı oldukça geniş bir türdür. Özellikle Mekke, Medine, Kudüs, Şam gibi İslam beldeleri hakkında yazılmış olan birçok fazilet-nâme bulunmaktadır (Yılmaz, 2017: 367-369). Bu çalışmada, bu türlere örnek teşkil eden ve konu olarak Oş’un faziletlerini işleyen Hayru'l-Buldan adlı risalenin, çeviri yazısı verilmiş ve eser, ses bilgisi ve şekil bilgisi bakımından incelenmiştir.

Çalışmaya kaynaklık eden el yazması, $12.5 \times 7.5$ cm ölçülerinde, arka ve ön kapağındaki cilt üzerinde salbek bulunan, şirazesi deri ve $3 \mathrm{~cm}$, her sayfasında 6 satır yazılı kısım olan bir eserdir. Yazmanın baş kısmı eksik olmakla birlikte eksik kısmın, mevcutlardan anlaşıldığı kadarıla söz konusu faziletnâmeden başka konuları, (ilmihal konuları) ele aldığı anlaşılmaktadır. Yazma, Molla Ömer Uzak tarafından kaleme alınmıştır; ancak yazmanın üzerinde herhangi bir tarih bilgisine rastlanmamıştır. İmam Nazar Oğlu Molla Umar Uzak'ın Oş’a bağlı Taşlak adlı yerde yaşadığı ve 1904'te Taşkent’te çıkarılmakta olan Türkistan Vilayetinin Gaziti adlı yayında Çarın Japonya'yı yenmesi için bir münacaat yayınladığı bilinmektedir (URL1). Hayru'l-Buldan adlı eserin farklı bir taş basma nüshasıyla ilgili Şehirlerin Faziletiyle İlgili Uydurma Hadisler ve "Hayru'l-Buldan" Risalesi adıyla Hakkı Ünal çalışma yapmıştır. Ancak bu çalışmada eser, çeviri yazı, ses bilgisi, şekil bilgisi açllarından incelenmiş değildir. Ünal'a göre, risalenin yazarı ilmî seviyesi düşük, kendi beldesini yüceltmek için halk arasındaki menkıbeleri toplamış bir kimsedir. Çünkü eserde hadis olarak verilmiş olan bilgiler uydurma hadis kitaplarında dahi bulunmamaktadır (Ünal, 2000: 81).

El yazması eserin faziletlerini anlattığı şehir günümüzde Tanrı dağlarına göçen Kırgızların çoğunlukla yaşadıkları (Çelik, 2020: 471) Oş şehridir. Kırgızistan'ın güneybatısında yer almakta olan Oş, ülkenin Bişkek’ten sonraki en büyük şehridir ve aynı zamanda Oş Bölgesinin de yönetim merkezidir. Şehrin tarihi, yazılı kaynaklarda bin yl öncesine gitmekle birlikte yapılan arkeolojik kazılarla bu tarih 3.00o yıl öncesine kadar götürülebilmektedir (Buyar, 2019: 14). Şehrin günümüzdeki nüfusu 322.000 iken bölgenin nüfusu 391.ooo'dir (URL2). Tacikistan, Çin, Özbekistan ile komşuluğu bulunan Oş’un hemen doğusunda Kaşgar bulunmaktadır ve şehir Batı Türkistan ile Doğu Türkistan arasındaki geçiş noktasında yer almakla beraber Fergana Vadisi'nin doğudaki başlangıç noktasıdır. Türk İslam tarihi ve medeniyetinde önemli bir yere sahip olan bu vadi buradan itibaren batıya doğru Maveraünnehir'e kadar uzanmaktadır. Bu yönüyle de şehir önemli bir konuma sahiptir. Oş tarihî çağlardan beri ipekli kumaş dokumacılığı ile ünlü iken (URL3) günümüzde daha ziyade tarım ve hayvancılıkla geçimini sağlamaktadır.

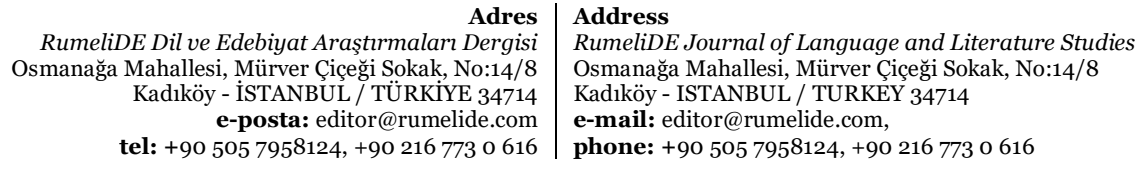


Bölgenin kadim şehirlerinden olan Oş’un adıyla ve kuruluşuyla ilgili pek çok rivayet bulunmaktadır. Bu rivayetler genellikle Hz. Süleyman'a dayandırılan, uzanan rivayetlerdir. Şehrin eteklerinde durulduğu dağın Süleyman Dağı adıyla anılması bunun bir göstergesidir. Rivayetlere göre Hz. Süleyman ordusuyla birlikte Süleyman Dağı'nın eteklerine gelince ordunun önünde giden öküzlerini durdurmak için Sart nidasıyla "Hooş" demiş ve öküzler durmuştur. Daha sonra burada kurulan şehre de Ho-oş sözünden türeme Oş denmiştir (Cumagulov, 2001: 3). Benzer bir efsanede ise Hz. Ademin'in öküzlerine "Uş" demesi üzerine, o beldenin adı da "Uş" olmuş ve zamanla bu Oş’a dönüşmüştür (Brudnıy ve Eşmambet, 2017: 378). Manas Destanı'nda ise Oş’a dair şöyle bir rivayet vardır: Manas'ın babası Cakıp, Manas'ı hayata hazırlaması için Oşpur adlı çobanın yanına vermiş ve Manas 5-6 yll onun yanında kalmıştır. Manas han olunca da Oşpur'a hürmetinden dolayı o civara şehir kurdurmuş ve Oşpur'u da o şehre yönetici olarak atamıştır. Bunun üzerine şehrin adı da Oşpur olarak kalmış ve bu isim zaman içersinde Oş’a dönüşmüştür (Rısbaev, vd. 2016: 263-264).

$\mathrm{Bu}$ çalışmada nitel araştırma yöntemlerinden doküman incelemesi kullanılmıştır. Aras,tırma kapsamında incelenen konuyla ilgili olgu ve olaylar hakkında bilgi içeren yazılı belgelerin analiz edilmesiyle veri sağlanmasına doküman incelemesi denilmektedir. (Yıldırım ve S,ims, ek, 2008: 188) Bu bağlamda; incelenen doküman öncelikle çeviri yazıyla Latin harflerine aktarılmış; ardından, elde edilen verilere dayalı olarak metnin dil özelliklerinin analiz ve değerlendirmesi yapılmıştır.

\section{2. Çeviri yazı}

$54 \mathrm{~b}$

(1) bismi'l-lāhi'r-raḥmāni'r-raḥim

(2) bu risāle hayru'l-buldān kim ya' ni O- (3) -ş şehrini fażìleti turur andag̉ rivā-(4)-yet ḳılurlar kim bul hạaișni ‘ İmrān ib(ni)

$55 \mathrm{a}$

(1) Hususayn, Peygamber șalla'l-lāhu ' aleyhi ve sellemdin (2) kale'n-nebī ' aleyhi's-selām innā'llahe maşrık beldeten (3) ta'alā Oş ve hüve hayru'l-buleydeten vallāhü fașale (4) 'alā sāyiruhā ve ehl-i Oş 'alā sāyiri'l-ümem ve yahşur-(5)-ūne me'a'ş-şühedā'l-Bedri ve yahşuru'ş-şühedāi'l-e- (6)nbiyā’i hadīsnnin ma' nīsi ol kim hạażret-i

$55 \mathrm{~b}$

(1) peyġamber șallallāhü 'aleyhi ve sellem 'ināyet ḳ1lı aydılar (2) kim maşrık şehride bir şehri bardur atını (3) ḩayru'l-buldān dirler ve şehr-i Oş hem dirler (4) köp yahşı şehrdür ve köp fażiletlık érür (5) ḳıyāmet küni āmennā ve șaddaḳnā bolġandı halāyıḳ- (6) -lar maḩşūr bolurlar ve oşalı kün bu Oş halḳı

$56 \mathrm{a}$

(1) şehīdler birlen şehīdü’l-Bedr peyġamber birlen ḥaşr (2) bolurlar ḥażret-i Ebū Hüreyre Hażzeti Muhammed Musțafa (3) șallallāhu 'aleyhi vesellemdin eşitipdirler kim yer- (4) -yüzide bir cemā'a ādamlar peydā bolur Nūḥ (5) 'aleyhi’s-selāmnı neslidin könülleri ḳatg̉unı (6) raḥm ümmetlerimni arasıda alardın köp fesād-

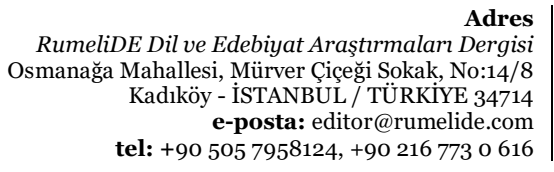

Adres
RumeliDE Dil ve Edebiyat Araştırmaları Dergisi Kadıköy - ISTANBUL/TÜRKiY tel: +90 505 7958124, +902167730616
Address

RumeliDE Journal of Language and Literature Studies

Osmanağa Mahallesi, Mürver Çiçeği Sokak, No:14/8

Kadıköy - ISTANBUL / TURKEY 34714

e-mail: editor@rumelide.com,

phone: +90 $5057958124,+902167730616$ 
(1) -lar kilür ve ba`ż̇ şehrlerni tārāc ḳılıp dīn- (2) -ni ġāret kıllgaylar ve köp şehrlerni buzġay-(3) lar Huday ta'āalā bu Oş şehrini ol cemā' at-1 (4) bedni şerridin saḳlaḳay anıj üçün bu şehr-(5) -ini belde-i ma‘ șūm dirler ve taḳı Huužeyfe-i Yemānī (6) digen büzrük müştehīdü’l-kirām rivāyet

$57 \mathrm{a}$

(1) ḳılurlar kim hażretī peyġamber 'aleyhi’s-selāmdın kim (2) su'āl ḳıldım yā Rasū'l-allāh bizge Oşnı (3) fażīletidin ve a'māl ü ef âlleridin (4) beyānı ḳılı̣ dédim érse hażret-i rasūl (5) 'aleyhi’sselām yana ' ināyet ḳılıp aydılar kim (6) Oş ehlini fażiletleri köpdür bir yahşs

$57 \mathrm{~b}$

(1) fażìlet bul turur kim bir cemā`a halḳ bar (2) érmişler alarnı̀ atını ḳaṭbun dir érmiş- (3) -ler alarnı dīni bī-gāne érmiş Oş ḩalḳı olar (4) birle köp gazāt ḳılur érmiş ve taḳı müştehīd- (5) -ler andağ rivāyet ḳılurlar kim her kimerse Oş-(6)-g̉a barsa yā bir kice yā bir kün tursa ol kişi günāh-

$58 \mathrm{a}$

(1) dın andag bolġay ve Oş ehlidin (2) bolġay ḳıyāmet küni hem Oş ehli birlen (3) mahş̧ūr bolurlar ve taḳı rivāyet ḳılurlar kim (4) her kişinin vaḳti yetip Oş şehride (5) ḳażā ḳılsa șevābı yüzidin andag bolġay ki (6) özge yernin şehīdleri birle berāber bolg̀ay

$58 \mathrm{~b}$

(1) sevāblar yüzidin andag bolġay kim a' māl kā- (2) -tipleri bitmekdin ' āçiz kilgeyler ve taḳı (3) her kim olar birle namāz oḳusa cemā' at bolusa (4) ḳıyāmet küni Oş yeridin baş köter- (5) -geyler ve hażreti Emīiü'l-Mü'mīnīn 'Ömer rażıya'l-lāhü 'anhü (6) aydılar kim hażret-i peyġamber șa'llallāhü ‘aleyhi ve sellem-

$59 \mathrm{a}$

(1) -din andag rivāyet ḳlurlar kim peyġamber șa'll-a (2) llāhü 'aleyhi ve sellem aydılar kim men birāderim Cebrā'īl (3) 'aleyhi's-selāmdın su’āl ḳıldım kim ḳıāmet-(4)-de Oş ehli kim birle haşr bolur Cebrā'il 'aleyhi's-selām (5) aydılar kim siznin birle haşrr bolurlar ve (6) Emīiü'l- Mü 'minīn şāh-1 merdān murtażā ‘Alì aydılar

$59 \mathrm{~b}$

(1) aydılar kim men andag் eşittim ḥażret-i rasūl (2) 'aleyhi's-selāmdın kim tạla ḳıyāmet künide (3) Oş ehli barçaları közleridin yüzler (4) mišl-i āftāb-1 tābān yüzlük ... Burāke-suvā-(5) -re ḳopgiaylar alarnı hādimleri nūrdın ḳılıçlar (6) ḳolları́ga alıp tekbīi ü tehlīl ayıtıp ferişteler

$60 \mathrm{a}$

(1) șaf șaf tutup ilgerü keyin behişt-(2)-ġa alıp kirgeyler ve hażreti $\mathrm{H}^{\mathrm{v} a ̄ c e}$ 'Ukkāşe (3) rażıya'l-lāhü ' anh șahāābe-yi kirām érdiler bu söz-(4)-lerni eşitip bu kelimātnı aydılar kim (5) tabūni leküm yā ma'şera'l-'acem ya' ni Oş şehri barça (6) şehirlerni yahşşıı turur ve her kim Oşda bir zamān

$60 \mathrm{~b}$

(1) dem alsa veya bir demi su éçse veya bir loḳma ța āmı (2) yese gūr ' azābıdın cān açı่̇ıdın ve (3) Münker Nekirnin su'ālidin emīn bolup (4) șıraṭ köfrikidin āsān ötkeyler (5) ve yana ḥażret-i Șalmān1 Fārs-i ' adl-i mehtāb (6) rivāyet ḳılurlar kìm peyg̉amber șalla'lāhu 'aleyhi ve

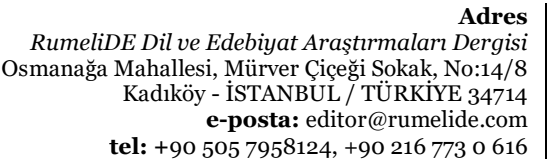

RumeliDE Dil ve Edebiyat Araştırmaları Dergisi tel: +90 505 7958124, +90 2167730616
Address

RumeliDE Journal of Language and Literature Studies Osmanağa Mahallesi, Mürver Çiçeği Sokak, No:14/8

Kadıköy - ISTANBUL / TURKEY 34714

e-mail: editor@rumelide.com,

phone: +90 505 7958124, +90 2167730616 
$61 \mathrm{a}$

(1) sellemdin öz mübārek lafẓlarıdın éşittü- (2) -k aydılar kim ol kiçe kim meni āsmānġa çıḳganda (3) yeryüzide bir nūr kördüm maşrık sarıdın (4) ol āsmāng̉a çıḳıp baradur baḳī gūristān- (5) -1 dağ1 nūrg̉a ohş̧apdur birāderim Cebrā- (6) - 'ildin suradım bu niçük nūrdur dip-

$61 b$

(1) -dür Cebrā 'il 'aleyhi's-selām aydılar kim yā Muḥammed (2) ol nūr Oş şehridin çıḳar ol şehr(3)-nị atını Hुayru'l-Buldān dirler burun zamān (4) Ḩażreti Süleymānı ' aleyhi's-selām ol şehrde ḳarar (5) tapıp dād u ‘ adl ḳılur érdiler ve o (6) tag̉da ol fażiletlı̣̣ maḳāmıda bir mescid

$62 \mathrm{a}$

(1) bar Ḩażreti Süleymān 'aleyhi's-selām ol (2) mescid içinde makșūdları̀ga yetkenler (3) ve her kim anda barıp ékki rek` at namāz oḳu- (4) -sa günāhdın māder-z̄ād pāk bolup (5) anı̣ içinde hịç günāh ḳalmag̉ay șevā- (6) -bı yüzidin andag bolg̀ay ki tört

$62 b$

(1) yüz rek` at namāz özge yerde namāz oḳuġa-(2)-n dik bolġay ve Hażreti peygamber șalla-lāhu (3) 'aleyhi ve sellem Ḥażret-i Mihter Cebrā'il 'aleyhi's-selā- (4) -mdın eşitip érdiler aydılar kim birāderim (5) Cebrā 'il men uş yerde ol fażīlet- (6) -lık maḳāmıda ékki rek` at namāz oḳusam

$63 \mathrm{a}$

(1) dip arzu ḳıldılar érse şol sā' at (2) Cebrā 'il 'aleyhi's-selāmġa Allāh ta' ālādın (3) fermānı boldı kim yā Cebrāं il ol tag̉nı (4) köterip alıp çıḳgıl tā çıḳıp ol tag̉d- (5) -a ve ol fażiletlıḳ maḳāmıda ékki re- (6) $-k^{c}$ at nemāz oḳusun līkin andag

$63 \mathrm{~b}$

(1) çıḳarg̉ıl kim Oş ḩalḳı tuymasunlar (2) Cebrā 'il ' aleyhi’s-selām Huudāy 'azze ve cellenin fermā(3)-nı birle Oş tağını çıḳardılar rasūl (4) 'aleyhi's-selām ol mübārek tag̉da ve o- (5) -1 fażīletlı̣ maḳāmıda Ḥażret-i Süleymān (6) namāz oḳup secde țấ' at ḳılg̀an yerni

$64 \mathrm{a}$

(1) țavāf ḳılıp ve anda ékki rek`at namāz o- (2) -ḳudılar ve heme ötken peyġamberlernin haḳları-

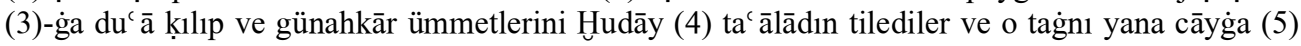
yiberdiler Oş ḩalḳı tuymadı anın (6) üçün kim ol mübārek tag̉nı atnı bera-

$64 \mathrm{~b}$

(1) -ber el-kūh dirler ve taḳı andag naḳl ḳılur-(2)-lar kim șaḥih rivāyetde kiltürüpdürler (3) kim Hażret-i Yūnus ‘ aleyhi’s-selām Oş şehrig̉a (4) kilip érdiler ve Oş ḩalḳı olarg̉a be-tev- (5) -fiḳ īmān kiltürüp érdiler ve köp (6) yıllar ol mübārek tag̉da ve ol

$65 \mathrm{a}$

(1) fażīletlıḳ maḳāmda namāz oḳup țā-(2) - ' at ḳılıp Oş şehride ékenler neçe (3) vaḳtdin son Oş ehlig̉a Hażret-i (4) Süleymān 'aleyhi's-selām hem Oş şehriğa (5) kilip tahtlarını ol mübārek tag̉ga (6) ḳurdılar Oş şehri olarğa hem

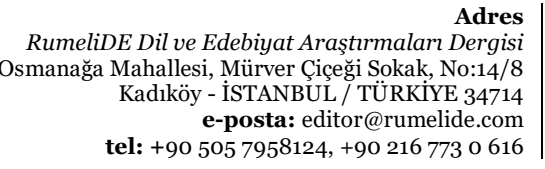

Adres
RumeliDE Dil ve Edebiyat Araştırmaları Dergisi
Osmanağa Mahallesi, Mürver Çiçeği Sokak, No:14/8
Kadıköy - İSTANBUL / TÜRKIYE 34714
e-posta: editor@rumelide.com
tel: +90 505 7958124, +90 216 7730616

Address

RumeliDE Journal of Language and Literature Studies

Osmanağa Mahallesi, Mürver Çiçeği Sokak, No:14/8

Kadıköy - ISTANBUL / TURKEY 34714

e-mail: editor@rumelide.com

phone: +90 5057958124 , +90 2167730616 
(1) be-tevfik īmān kiltürüpdüler ve (2) Süleymān 'aleyhi’s-selām Oş ehlini (3) ḥaḳlarıġa du`ā kııldılar (4) (5) (6) ${ }^{3}$ şehr-i Oşģa küfr ḳarār tapmadı

$66 \mathrm{a}$

(1) andın son Oş ehli Ḥażret-i Süleymān (2) 'aleyhi’s-selāmġa aydılar yā peyġamber Huday ta ‘̄āā

(3) pādişāh-1 'ālem bu Oş şehrini suy azlık ḳıladur (4) munca kişige kifāye ḳılmaydur ve eger siz bir

(5) ‘ilāc ḳılıp su kiltürseniz bihraḳ bolur (6) érdi iltimās ḳıldılar andın son Ḥażret-i

$66 b$

(1) Süleyman 'aleyhi's-selām țạt ḳılıp ve bularnı emri (2) ḳıldılar kim ol tag̉ kim sunı turar érdiler (3) ol tağnı kisip sunı aḳuzuylar didiler (4) derḥāl Süleymān peyġamberni emriylen ol tag̉nı (5) kisip sunı aḳuzdılar andın keyin ol zamandın (6) bu zamāngaaça Oş şehri sir-āb boldı

$67 \mathrm{a}$

(1) dipdürler ve taḳ1 $\mathrm{H}^{\mathrm{v} a ̄ c e}$ Yemānī gaāzi (2) digen ‘ azīz bu Oş şehrig̉a kilip érdiler (3) ol ‘azīz ḥażreti 'İsā ' aleyhi's-selāmnın dīnler- (4) -ig̀a érdiler müddet ékki <yüz> yıl bir namāzda Huday ‘ azze (5) vecelleg̉a țā'at ve 'ibādet ḳılıp érdiler ol (6) vaḳtde Oş ehli fażīletidin eşitip

$67 b$

(1) Rabbü'l-' azzetdin tiler kim ey Bār-Hुudāyā (2) menin hem ḥaşrım Oş ehli birle bolsun dip Hudā(3) -y ta alā du' ālarını icābet ḳıldı bu Oş şehrid- (4) -e ḳażā ḳılıpdurlar ve olarnın türbetleri (5) nemāzgāh yatavğı daġı tag̉nı étegide turur ve taḳı (6) Medine ’i Münevveredin ba' żı büzrükler olarnı

$68 \mathrm{a}$

(1) ziyāretlerig̉a kilipdurlar ve yana 'azīz bir (2) 'İmrān hāas atlık Oş şehrigia bar ékenler (3) sipahsālar leşker érdiler köp küffār (4) birlen gazāât ḳlur érdiler künlerde bir kü- (5) -n küffār birle gazāt ḳlıp érdiler tünler- (6) -igga köp gerd olturup érdi el-hạāl ol tü-

$68 \mathrm{~b}$

(1) -tünni ḳatıp érdiler ol tünni ayta (2) kirin ékki ḩışt țaā tüşüptür ve olar (3) kabirlerig̉a ḳoyupdurlar ol 'azīz-(4)-ni ḳabirlerig̀a nemāzgāhg̉a yavuḳ turur olarnı (5) ḳabrini ziyāret ḳılsa her murādı maḳșūı bolsa (6) Huday ta' ālā rivāyet ḳılg̉ay vaḳti andag̉ rivāyet

$69 \mathrm{a}$

(1) ḳılurlar kim İmām İsḥāḳ velī atlıḳ 'azīz (2) bar érdiler özleri Oşs şehridin ér- (3) -diler ve Mekke halḳı olarg̉a iltifātları köp (4) érdi ve olarnı mülāzemetide bar ékendür- (5) -ler kim meșcid vaḳt ékenler ya' ni aytıpdurlar (6) kim şunça ' azīz büzrük ve erler barçası

$69 \mathrm{~b}$

(1) Oş şehrini fażìletidin ve sebebidin (2) Oşda fevt tapıp medfūn boldılar ve taḳı (3) $\mathrm{H}^{\mathrm{v}}$ āce Aḥmed Erḳam atlıḳ bir 'azīz Oş şehr- (4) -ig̀a bar érdiler olar hem șāḥib keşf érdiler (5) ol 'azīzni bir kerāmetleri ol érdi kim (6) uş vaḳtde Oş ehli bir ḳurg̉an binā ḳılip

4. 5. satırlar ve 6. satırın başı mükerrer yazıldığı için tarafımızdan metinden çıkarılmıştır.

Adres Address

RumeliDE Dil ve Edebiyat Araştırmaları Dergisi Osmanağa Mahallesi, Mürver Çiçeği Sokak, No:14/8 Kadıköy - ISTANBUL / TÜRKIYE 34714 e-posta: editor@rumelide.com

RumeliDE Journal of Language and Literature Studies Osmanağa Mahallesi, Mürver Çiçeği Sokak, No:14/8

Kadıköy - ISTANBUL / TURKEY 34714 tel: +90 $5057958124,+902167730616$

e-mail: editor@rumelide.com

phone: +90 $5057958124,+902167730616$ 
(1) érdiler bir ulug taş ol ḳurgangàa (2) yavuk érdi Oş ehlini (3) hayālleride bul érdi kim oşal 'azīm (4) taşnı ḳurg̉anga étip ḳoyalek ḳurg̉a- (5) -nı̣ ibtidāsı şol taş birle bolsun (6) dip érdiler el-ḥāl ulug kiçik

$70 \mathrm{~b}$

(1) yı ġılıp kilip zūr ḳılsalar ol taşnı (2) ornıdın tebret'almadı 'āciz ve hayrān bo- (3) -lupdurlar

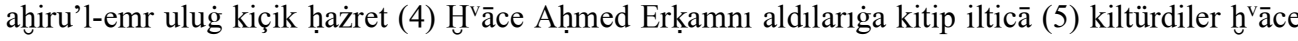
Erḳam aydılar édiler (6) kim sizler barıylar biz hem meded ḳılgay-

$71 \mathrm{a}$

(1) -miz dédiler andın son $\mathrm{H}^{\mathrm{v}}$ āce Aḥmed (2) Erḳam özleri yalg̉uz kilip ol ‘aẓīm taşnı (3) kerāmāt ḳ1ıp köterip iltip ḳurg̉an- (4) -nı tamig̉a ḳoydılar el-ḳıșṣa ḳurganı tamı ol (5) taş birlen binā bolupdur ve yana andag rivāyet (6) ḳılurlar kim $\mathrm{H}^{\mathrm{v}} \bar{a} c e$ Aḥmed Nerm $\mathrm{H}^{\mathrm{v}} \bar{a} \mathrm{c} e$ Aḥmed

$71 \mathrm{~b}$

(1) Erḳam on bir Aḥmedni ékkisidürler kim bir kün ribāṭ (2) ḥavż-1 sīm-keşde ékevlen va' $z$ aytur édiler (3) buḳalar ḳaçḳırıp olarg̉a köp teşviş berip- (4) -dürler Ḩ$^{\mathrm{v}} a \bar{c} e$ Aḥmed-i Nerm aydılar kim ey bukalar köp (5) sözlemenler didiler ol zamāndın bular (6) menğaça ol söz bilen buḳalar ol havavżda

$72 \mathrm{a}$

(1) hīç ün çıḳarg̉anı yoḳ ve hịç kim o- (2) -1 ḥavżda buḳanı āvāzını eşitgeni yoḳ (3) dipdürler ve taḳı naḳl ḳılurlar kim bir kün (4) Hु̛āce Aḥmed Nerm Ribāṭ̂ havż meskende țahā- (5) -ret ḳ1lıp olturğanlarıda behişt (6) ḥūrileri o ‘ azīznin közlerig̀a körünüp

$72 b$

(1) yā $H^{v} \bar{a} c e$ Aḥmed Nerm közünizni bizni (2) sarı ḳılı̣ ve mübārek yüzinüzni bizd-(3)-in ögürmen kim bizler siznin (4) aytḳanlarınızdur-miz bilin kim tạla (4) namāz-1 pişsīn vaḳtide merg şerbetin (5) içip bizge ḳoşulur-siz dédiler

$73 \mathrm{a}$

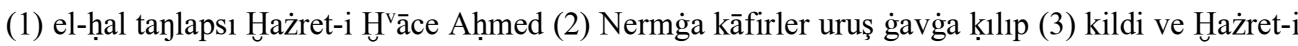

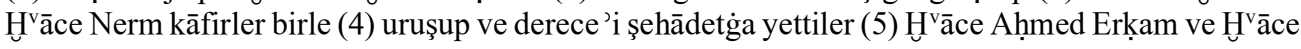
Aḥmed Nerm ékki (6) büzrük var oşol tag̉nı ve dāmeneside

$73 b$

(1) Ribāt-1 Ḥavż-1 Simkeşde medfūn bold-(2)-1lar her kim ol ékki 'azīzni ziyāret ḳılsa (3) Ḥaḳ sübhānehü ve ta'ālā cümle murād-ı makṣūdı (4) bolsa yetkürgey ve taḳı rivāyet ḳılur (5) kim Hażreti Âș̣af ibn Burhiyā büzrük (6) Hạ̇ret-i Süleymān ‘aleyhi’s-selāmnı țag̉a-

$74 \mathrm{a}$

(1) -ları érdiler ve hem vezīrleri (2) érdiler olardın köp kerāmat zā-(3)-hir bolg̉anı érdiler bir kerāmatları (4) ol érdi kim Belḳısnı̀ tahtını köz yumu -(5) -p açğunça kiltürüp érdiler anda-(6)-g kim Perverdigār-1 ‘ ālem öz kelāmıda ḩaber

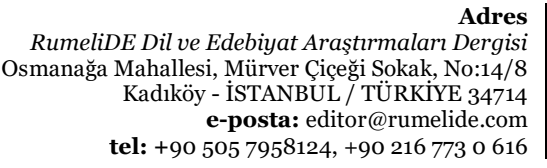

Adres

8

RumeliDE Journal of Language and Literature Studies Osmanağa Mahallesi, Mürver Çiçeği Sokak, No:14/8

Kadıköy - ISTANBUL / TURKEY 34714

e-mail: editor@rumelide.com,

phone: +90 5057958124 , +90 2167730616 
(1) beripdür knavlühü ta' ālā “kāle'l-lezī 'indehü(2) 'ilmun mina'l-kitābit ene ātike [bihī] kable en yer[tedde] ileyke (3) tarafüke " "ve ' aḳāyid kitābnı mes 'elesidür kim (4) evliyālarnı kerāmātı hạaḳur Hażreti (5) Āṣaf ibn Burḩıyā Oşda mescid ziyāretde (6) vefāt tapġan érmişler Hażret-i Süleymā-

$75 \mathrm{a}$

(1) -n 'aleyhi's-selām ḩayālleride bu (2) érdi kim Ḥażret-i Āṣafnı mag̉rīb (3) sarı̀ga alışıp ketgiler Cebrā 'īl 'aleyhi's-selām (4) Süleymān 'aleyhi's-selāmġa hyaber berdi kim Huda-(5)-y 'azze ve cellenin emri buldur kim Āṣaf- (6) -nı Oş yeride defn ḳılsun her kimni

$75 b$

(1) tilegi ve hāceti bolsa Hażreti Āṣaf (2) ibn Burhıyānın ziyāret ḳılsa ve her murādı (3) makṣ̂̄dı bolsa revā ḳılur-men ve müşkil (4) éşlerini āsān ḳılur-men her murā- (5) -dı maḳṣudlıg̉a yetkürürmen dip aytu- (6) -r her kim tilegi ve hậ̄eti bolsa revā bolur

$76 \mathrm{a}$

(1) ve yana rivāyet ḳılurlar kim Ḥażret-i Süleymā- (2) -n 'aleyhi’s-selāmnın zamānların tö-(3) -rt min yıl olturup érdi kim (4) bu risāle münderic boldı dipdür ol (5) zamānda ḳıble Beytü’l-Maḳdīs érdi ve namāz- (6) -nı̀ Beytü'l-Maḳdīs bakıp okur érdi-

$76 b$

(1) -ler biznin peyġamberimizin zamānlarıda (2) ḳıble Ka` be boldı andag̉ kim Haḳ ta' ālā kelām-1 (3) mecīdde haber beripdür kim ḳavlühü ta' ālā "vecheke (4) şatra'l mescidi'l-harām ${ }^{6}$ " bu ḳıble $\mathrm{Ka}^{\prime}$ be bolmaḳıg ga (5) delālet ḳılur ve yana andag rivāyet (6) ḳılurlar kim ḳıyāmet küni āmennā ve șaddaḳnā

$77 \mathrm{a}$

(1) bolg̉anda Oş yeridin nece min (2) șādık érenler ve nece min Kurān- (3) - $h^{\vee}$ ān érenler ve nece min ehl-i sehāvet (4) ehl-i sa'ādet érenler ve nece mị (5) namāzīlar ve nece mīy şehidler (6) ve nece min 'azīz meşāyıh érenler (7) Oş yeridin baş köter-

$77 \mathrm{~b}$

(1) -geyler ve taḳı andag (2) naḳı ḳılurlar kim her kim kiçesi Oş yer-(3)-inde țầ at ḳılsa șevābı yüz yerin and- (4) -ag் bolġay ki hac becā (5) kiltürmiş dik bolġay ve yetmiş (6) mị mertebe ġazāt ḳılġan dik bolgay

$78 \mathrm{a}$

(1) ve taḳı her kim bu risāleni oḳusa yā oḳutu- (2) -p eşitse yā tapıp özige saḳlasa (3) cemīi enbiyā ve evliyālar ol kişige meded (4) terbiyet ḳılsa anındın ḩoşnūd bolġa-(5)-ylar tạla ḳıyāmet küni şefā' at (6) ḳılg̀aylar ol kişiyi pīr-i behişt

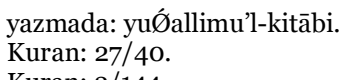

RumeliDE Dil ve Edebiyat Araştırmaları Dergisi Osmanağa Mahallesi, Mürver Çiçeği Sokak, No:14/8 Kadıköy - ISTANBUL / TÜRKIYE 34714 e-posta: editor@rumelide.com tel: +90 505 7958124, +90 2167730616
Address

RumeliDE Journal of Language and Literature Studies Osmanağa Mahallesi, Mürver Çiçeği Sokak, No:14/8 Kadıköy - ISTANBUL / TURKEY 34714 e-mail: editor@rumelide.com, phone: +90 5057958124, +90 2167730616 
$78 \mathrm{~b}$

(1) ve țarịkat-i hażret-i sulțānü'l-`arifīn (2) Hل̂̃āce Aḥmed Yesevī aytıpdurlar kim her kimesi (3) bu du' ānı künde üç mertebe oḳusa eger oḳu- (4) -y’almasa özige saḳlasa Hażreti Huıżır 'aleyhi's-selām (5) körünüp aya meded ve terbiyet ḳılıp hem (6) kiçe hem kündüz hem-rāh bolup yürgeyler

$79 \mathrm{a}$

(1) devlet ve mertebesi ziyāde bolġay ve yüz (2) yegirmi beş yıl 'ömr-i țab' ỉdin nașīb ḳılg̀ay (3) ve heme ḳılġay yamān ' amelini yahşslikge mübeddel (4) ḳılg̉ay ve her țaleb-i müdde` āsı bolsa tegürgey ve a- (5) -nı̣ kesb-i kārıga ve hānedānıġa kündin (6) tünge bereket bergey ve her kim şek kiltürse

$79 b$

(1) kāfir bolg̉ay ne ūzu billāhi min zāalike (2) du`ā: bu turur bismi’r-raḥmāni’r-rahīm emānan minke

(3) yā seyyide'l-mürselīn unẓurnī bi-ḥaḳḳı bismi'r-raḥmāni- (4) -'r-rahịim

temmet el-kitābu (5) bi-' avni'l-meliki'l-vehhā- (6) -b bi-raḥmetike (7) yā erḥame'r-rāḥimīn

$80 \mathrm{a}$

(1) tū-be-tū fisḳ u ḩarāmīi lā-yenām

İn kitābet rūz-1 çehārşenbe tamām

Her ki ḩā̄ned du'ā țama' dārem

Zān ki men bende günehkārem

Raḳama Molla Ömer Uzaḳ

\section{Dil özellikleri}

\section{Ses bilgisi.}

\section{Ünlü Olayları}

Vurgusuz orta hece ünlüsünün düşmesi: şehrini $54 \mathrm{~b} / 3$

Başta ünlü düşmesi: $\mathrm{d}>\mathrm{y}$ : yéberdiler 64a/5 (Ida bér>iyéber> yéber) (Argunşah, 2018: 105)

Ortada ünlü düşmesi (kelime birleşmesi neticesinde): bolurlar 56a/2 (bol> bu+ol) (Argunşah, 2018: 105)

Ünlü Birleşmesi: ék+ev+len 71b/2 (éki +egü > ékegü > ékev)

\section{Ünsüz Olayları}

k $>$ h: yahşs $55 \mathrm{~b} / 4$, ohşsapdur $61 \mathrm{a} / 5$

\footnotetext{
7 Uyumadan, sürekli günah ve haramla bu kitabın yazımı çarşamba günü tamamlandı. Bu kitabı kim okursa ondan dua bekliyorum. Çünkü ben günahkâr bir kulum.

RumeliDE Dil ve Edebiyat Araşturmaları Dergisi Osmană̆a Mahallesi, Mürver Çiçeği Sokak, No:14/8 Kadıköy - ÍSTANBUL / TÜRKIYE 34714 e-posta: editor@rumelide.com tel: +90 $5057958124,+902167730616$

Address

RumeliDE Journal of Language and Literature Studies Osmanağa Mahallesi, Mürver Çiçeği Sokak, No:14/8

Kadıköy - ISTANBUL / TURKEY 34714

e-mail: editor@rumelide.com,

phone: +90 505 7958124, +90 2167730616
} 
$\mathrm{m}>\mathrm{b}$ : burun $61 \mathrm{~b} / 3$

t>d dérler 61b/3, dék 77b/5

b $>\mathrm{y}$ suy $66 \mathrm{a} / 3$

g>k: kiçik

p>f: köfrikidin

$\mathrm{d}>\mathrm{y}:$ keyin $60 \mathrm{a} / 1$

$\mathrm{g}>\mathrm{w}>\mathrm{v}: e^{2}+\mathrm{ev}+\mathrm{len} 7 \mathrm{1b} / 2$

v>y>g: ögürmen $72 \mathrm{~b} / 3$

y türemesi: $y \dot{g}+1 a-p 70 b / 1$

ünsüz ikizleşmesi: ékki 62b/6

r düşmesi: bilen $71 \mathrm{~b} / 6$, édiler $7 \mathrm{ob} / 5$

Çağataycada $\mathrm{t}>\mathrm{d}$ değişmi sonucu takıı dagi, tag $>d a \dot{g}$ olması gerekirken bu ses değişimleri metinde bulunmamaktadır. takı $58 \mathrm{~b} / 1, \operatorname{tag} 66 \mathrm{~b} / 2$

Metinde tonlu tonsuz uyumu bulunmamaktadır (Oşda 60a/6, yahşıllikge 79a/3). iki ve daha çok heceli isimlerin sonlarındaki k/g/g seslerinin varlığını korumaktadır (andag $58 \mathrm{a} / 1$, ulug $7 \mathrm{ob} / 3$ ). Bunlar dışında eski Türkçede sub, Çağataycada ise $s u$ (Güzeldir, 2002: 357), suvveya suu(Ünlü, 2013: 1012) olan sözcük, Nevaî Divanı'nda olduğu gibi (Eckmann 2009: 139) bir yerde suy 66a/3 (b>y) şeklinde bulunmaktadır. $\mathrm{Bu}$ durum eb>ew>öy, üy (Yürümez, 2020: 31-32) seb>sew>sev değişimlerinde slkça karşımıza çlkmaktayken su sözcüğünde slk görülen bir durum değildir. Çağataycada var olan "é" metinde de bulunmaktadır (éşlerini 75b/4, érür 55b/4). Arapça 'aciz kelimesi bir yerde 'açiz (58b/2) olarak yazılmıştır.58b/2. Metinde, Türkçe kelimelerin yezımında "p/b" karışık olarak bulunmaktadır, tüşüptür $68 \mathrm{~b} / 2$.

Oğuzcanın etkisiyle Çağataycada yuvarlaklaşma olabilmektedir. Metnimizde buna birçok örnek bulunmaktadır. ilgerü 60a/1, éşittük 60a/1-2, tuymasumlar 63b/1 gibi.

\section{Şekil Bilgisi}

\section{Yapım Ekleri}

\section{İsimden İsim Yapma Ekleri}

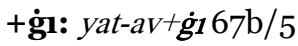

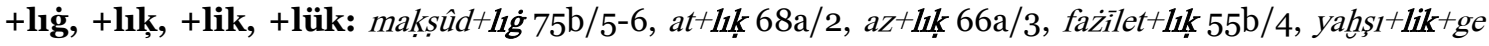
79a/3, yüz+lük 59b/4-5

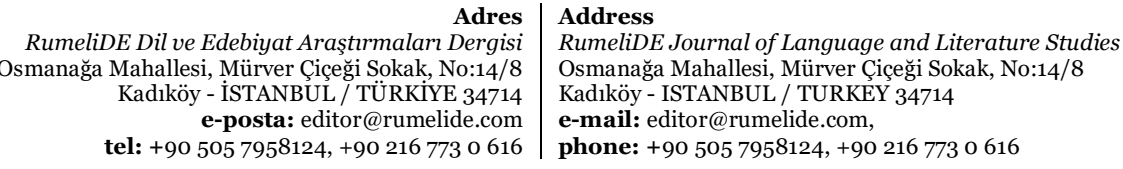




\section{Fiilden İsim Yapma Ekleri}

-av: $y a t-a v+\dot{g}_{1} 67 \mathrm{~b} / 5$

-én: ér-en+ler 77a/2 77a/3

$+\mathbf{k}(\mathbf{g}):$ tile-g-i $75 \mathrm{~b} / 1$

-ma: kal-ma-ġay 62a/5-6, oḳu-y-al-ma-sa 78b/3-4, tap-ma-dı 65b/6, tuy-ma-dı 64a/5

-mAk: bol-mak-1+ga 76b/4, bit-mek+din 58b/2

-uş: ur-uş $73 \mathrm{a} / 2$

\section{İsimden Fiil Yapma Ekleri}

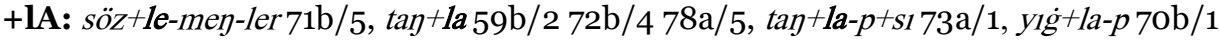

\section{Fiilden Fiil Yapma Ekleri}

-a-: $\operatorname{sur}-\mathrm{a}-\operatorname{dim} 61 \mathrm{a} / 6-61 \mathrm{~b} / 1$

$-\mathbf{a r}: c ̧ ı k-a r-\dot{g} a n+172 \mathrm{a} / 1-2$

-kür, -kır (<-gUr-): $\quad$ yet-kür-gey73b/4, kaç-kır-ıp 7ob/3

-t, -tür:ayla-t-ıp 71a/3-4, ay-t-ur 71b/2, kil-tür-di-ler 70b/5, kil-tür-miş 77b/5

-ul: $k o s s-u l-u r-s i z 72 b / 6$

-1ş, -uş: al-ış-1p 75a/3, ur-uş-up 73a/4

-uz: ak-uz-di-lar66b/5, ak-uz-uy-lar66b/3

-ün: kör-ün-üp $72 \mathrm{a} / 6$ 78b/5

-ür : tig-ür-gey-nin 79a/4-5, tig-ür-ür-men 75b/5-6

\section{İsim Çekimi}

\section{Çokluk Eki}

-1ş: al-ış-1p 75a/3

+lAr: ādam+lar 56a/4, aldı+lar+1+ga 70b/4, barça+lar+159b/3, buka+lar 71b/3-4 71b/4 71b/6, büzrük+ler 67b/6, er+ler 69a/6, ér-en+ler 77a/2 77a/3 77a/4 77a/6, hādim+ler+i 59b/5

\section{İyelik Ekleri}

+1m, +im: haşrr+ım 67b/2-3, birāder+im 59a/2, ümmet+ler+im+ni 56a/6-56b/1




+in: $m e n+i n 67 \mathrm{~b} / 2-3$

+I / +sI: şerbet $+i+n 72 b / 5, a t+1+n 155 \mathrm{~b} / 2, a r a+s 1+d a 56 a / 6$

+imiz: peygamber+imiz $+i n 76 \mathrm{~b} / 1$

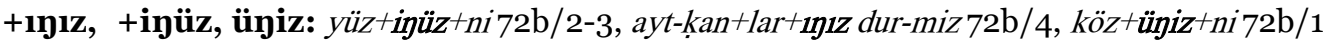

+lArI: $k o l+l a n+\dot{g} a 59 \mathrm{~b} / 6$

\section{Zamir "n"si}

+n: yer+i+n+de 77b/3-4, şu+n+ça 69a/6, yer+i+n+de 77b/2-3. Zamir n'sinin kullanılmadığı sözcükler de bulunmaktadır. ara + si $+d a 56 \mathrm{a} / 6-56 \mathrm{~b} / 1$

\section{Aitlik Eki}

+ki: $k o ̈ f r i+k i+d i n 6 o b / 4$

\section{Durum Ekleri}

\section{Yalın Durum}

\section{İlgi Durumu Eki}

+nı: Oș+nı fażiletidin 57a/2-3

+nıy, +nin: alar+nın 57b/2-3, Belkıs+nı 74a/4-5 kurga +nın 70a/4-5, kişi+nin 58a/4, peyǵamber+ler+nin 64a/2-3, șehr+nin 61b/2-3

+sl, +si: barça+s1 69a/6, ara + si + da $56 \mathrm{a} / 6-56 \mathrm{~b} / 1$, ibtidā+s1 70a/5, yahşı + si $60 \mathrm{a} / 6$, kiçe + si $77 \mathrm{~b} / 2-3$, emne + si + de $73 \mathrm{a} / 6$

$+\mathrm{i}:$ yer $+i+n+d e 77 \mathrm{~b} / 3-4$

\section{Belirtme Durumu}

+1, +(y)i: barça+lar+1 59b/3, fermān+1 63a/3, açıg $+1+d$ ln 6ob/2, aldı+lar $+1+\dot{g} a$ 70b/4, süleymān+1 61b/4, uşal+155b/6, fażilet $+154 \mathrm{~b} / 3$, emr $+i 66 \mathrm{~b} / 1$, kabir + ler $+i+g a$ 68b/3, kabr $+i+(n) i 68 \mathrm{~b} / 5, k i s i+y i ~ 78 \mathrm{a} / 6$

+n1, +ni: alar+n1 57b/3, āṣaf+n1 75a/2, buḳa+n1 72a/2, evliyā+lar+n1 74b/4, su+n1 66b/3, aḥmed+ni 71b/1, bed+ni 56b/4-5, kim+ni 75a/6,

+1n: zamān+lar+ın 76a/2-3

+n: şerbet $+i+n 72 b / 5$

\section{Yönelme Durumu}

+e: ziyāret+e $74 \mathrm{~b} / 5$

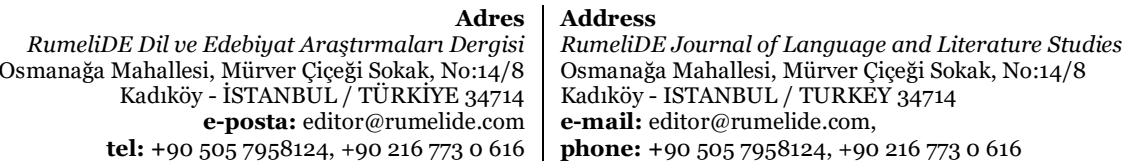




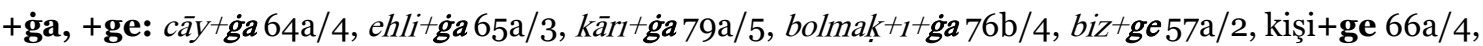
nerm + ge $73 \mathrm{a} / 3$

\section{Bulunma Durumu}

+dA: ḥavŻ+da 71b/6 72a/2, makām+da 65a/1-2, namāz+da 67a/4, ara+sı+da 56a/6-56b/, oş+da 60a/6, kün+de 78b/3-4, mesken+de 72a/4-5, emne+si+de 73a/6

\section{Ayrilma Durumu}

+dın, +din: nûr+dın 59b/5, sarı+dın 61a/3, günāh+dın 62a/4, kün+din 79a/5, bit-mek+din 58b/2, sebeb $+i+\operatorname{din} 69 \mathrm{~b} / 1$,

\section{Eşitlik Durumu}

+ça, +nca: şu+n+ça 69a/6, men+g̈a+ça 71b/6, zamān+ǵa+ça 66b/6, +nca: $m u+n c a$ 66a/4

\section{Vasita Durumu}

+ylen: emr $+i+y l e n 66 \mathrm{~b} / 4$

+la: $\tan +1 \mathrm{a}$

\section{Sayılar}

\section{Asıl Sayılar}

bir 68a/1, ékki 62a/1, üç 78b/3, tört 76a/2-3, beş 79a/2, elli 70b/4, yüz yegirmi beş 79a/1-2, yetmiş min 77b/5-6, tört yüz 62a/6-62b/1,

\section{Topluluk Sayıları}

+evlen: ék+evlen $71 \mathrm{~b} / 2$

\section{Zamirler}

\section{Kişi Zamirleri}

men 59a/2, biz 70b/6 (bizge 57a/2), siz 66a/4 (sizler 70b/6, sizni 72b/1, siznin 72b/3), olar 57b/3 (olarga 64b/4, olarnı 67b/6, olarnin 69a/4, olardin 74a/2)

\section{İșaret Zamirleri}

bu 56b/6, bul 54b/4, o 64a/4, uş 62b/5, oşalı 55b/6, oşol 73a/6.

\section{İsim-Fiiller}

bit-mek+din $58 \mathrm{~b} / 2$






\section{Sifat Fiiller}

-en: ér-en+ler $77 \mathrm{a} / 2$

-gan, -gen, -ķan, -ken: çık-ġan 61a/2, bol-gan+da 77a/1, oḳu-ġan62b/1-2, dé-gen 56b/6, eşit-gen+i72a/2, ayt-kan+lar+1j1z+dur+miz 72b/4, yet-ken-ler 62a/2

\section{Zarf Fiiller}

-a+: ayt-a-kir-in 68b/1-2, bar-a-dur 61a/4-5, kı1-a-dur 66a/3

-gunça : aç-ġunça $74 a / 5-6$

-ken: bar-é-ken+dür-ler 69a/4-5, é-ken+ler 69a/5, öt-ken 64a/2-3, yet-ken-ler 62a/2

-p, -1p, -ip, -up, -üp: di-p 63a/1, oḳu-p 78a/1-2, ohşa-p-dur 61a/5-6, yıg்la-p 70b/1, al-1p 59b/6, al-1ş-1p 75a/3, bar-1p 62a/3-4, ét-ip 70a/4-5, iç-ip 72b/6, kil-ip-ér-diler 67a/2, bol-up 58b/3, tur-up 76a/2-3, ur-uşup 73a/4, kör-ün-üp 72a/6, tüş-üp-tür 68b/2

-a lek: $k o y-a+l e k 70 a / 4-5$

\section{Fiil Çekimi}

\section{Şahıs Ekleri}

\section{Zamir meşeli şahıs ekleri.}

-men: kıl-ur-men 75b/3, tig-ür-ür-men 75b/5-6

-miz: kıl-gay-miz 7ob/6-71a/1, dur-miz 72b/4

-siz: kִoş-ul-ur-siz 72b/6

-lar: bol-ur-lar 55b/6, dé-r-ler 56b/5

\section{2. İyelik meşeli şahıs ekleri.}

-k: éşit-tü-k 61a/1-2

-niz: kil-tür-se-niz 66a/5-6

-lar: ay-d1-lar 55b/1

\section{Emir menşeli şahıs ekleri.}

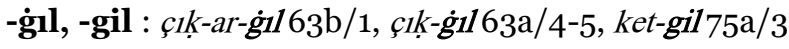

-sun: bol-sun 67b/2-3, kil-sun 75a/6

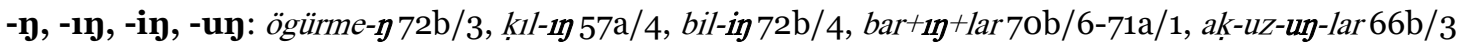

RumeliDE Dil ve Edebiyat Araştırmaları Dergisi Osmanağa Mahallesi, Mürver Çiçeği Sokak, No:14/8 Kadıköy - İSTANBUL / TÜRKIYE 34714 e-posta: editor@rumelide.com tel: +90 $5057958124,+902167730616$
Address

RumeliDE Journal of Language and Literature Studies Osmanağa Mahallesi, Mürver Çiçeği Sokak, No:14/8

Kadıköy - ISTANBUL / TURKEY 34714

e-mail: editor@rumelide.com,

phone: +90 505 7958124, +90 2167730616 


\section{Basit çekim}

\section{Bildirme kipleri}

\section{Görüilen geçmiş zaman}

-d1-m, -di-m, -dü-m, -ti-m: ḳ1-d1-m 57a/2, sur-a-d1-m 61a/6-61b/1, di-di-m 57a/4, kör-dü-m 61a/3, eşitti-m $59 \mathrm{~b} / 1$

-d1,-di: $k_{11-d 1}$ 67b/3-4, tap-ma-dı 65b/6, tuy-ma-dı 64a/5, ber-di 75a/4-5, kat-1p-ér-di-ler 68b/1-2

-tü-k: éşit-tük 61a/1-2

-d1-ler, di-ler, -ti-ler: ak-uz-dt-lar 66b/5, ay-dt-lar 55b/1, é-di-ler 7ob/5, yet-ti-ler 73a/4

\section{Öğrenilen Geçmiş Zaman}

-miş: ér-miş 57b/3, kil-tür-miş 77b/5, dirér-miş-ler 57b/2-3, bar+ér-miş+ler 57b/1-2

-1p, -ip, -up Dür-: kıl-1p-dur-lar 67b/4, eşit-ip-dir-ler 56a/3-4, kil-ip-dur-lar 68a/1, kil-tür-üp-dü-ler 65b/1, bol-up-dur 71a/5, bol-up-dur-lar 7ob/2-3

\section{Geniş Zaman}

-r, -ar,-ur, -ür: tile-r 67b/1, di-r-ler 55b/3, cılk-ar 61b/2-3, çı-ar-dı-lar 63b/3, çık-ar-g̈ll 63b/1, ay-t-ur 71b/2, bol-ur 56a/4, k1l-ur 57b/4-5, k1l-ur-lar 54b/4, kil-ür 56b/1-2

\section{Şimdiki Zaman}

-1p -dur-: çıkıp baradur 61a/4, ay-t-1p-dur-lar 69a/5, 78b/2

\section{Gelecek Zaman}

-gay, -gey, -kay, -key: bol-gay 58a/1, kal-ma-ġay 62a/5-6, kıl-ġay-miz 70b/6-71a/1, bol-ġay-lar 78a/4-5, buz-gay-lar 56b/2-3, ber-gey 79a/6, tig-ür-gey-nin 79a/4-5, kil-gey-ler 58b/2, yür-gey-ler 78b/6, sakla-kay 56b/4-5, öt-key-ler 6ob/4

\section{Tasarlama Kipleri}

\section{Emir Kipi}

-sun: bol-sun 67b/2-3, k1l-sun 75a/6, oku-sun 63a/6, tuy-ma-sun-lar 63b/1

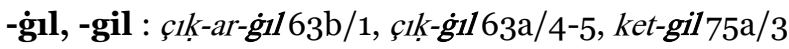

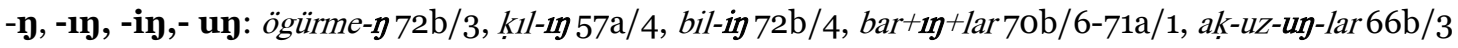

\section{Şart Kipi}

-sa, -se: oḳu-sa-m 62b/6, al-sa 6ob/1, bar-sa 57b/6-58a/1, bol-sa 68b/5, kil-tür-se-niz 66a/5-6, éç-se 6ob/1

\section{Adres $\mid$ Address}

RumeliDE Dil ve Edebiyat Araştırmaları Dergisi Osmană̆a Mahallesi, Mürver Çiçeği Sokak, No:14/8 Kadıköy - İSTANBUL / TÜRKIYE 34714 e-posta: editor@rumelide.com

RumeliDE Journal of Language and Literature Studies Osmanağa Mahallesi, Mürver Çiçeği Sokak, No:14/8 Kadıköy - ISTANBUL / TURKEY 34714 tel: +90 505 7958124, +90 2167730616 e-mail: editor@rumelide.com, 
eşit-se 78a/2, kil-tür-se 79a/6, kil-tür-se-niz 66a/5-6, oḳu-y-al-ma-sa 78b/3-4

\section{İstek Kipi}

-ma-y: k11-ma-y-dur 66a/4

\section{Gereklilik}

Birleşik Çekim

Hikâye Birleşik Zaman

Öğrenilen Geçmiş Zamanın Hikâyesi

-ip ér, -p ér, -up ér, -üp ér: kil-ip ér-di-ler 64b/4-5, dé-p ér-di-ler 70a/6, kil-tür-üp ér-di-ler 64b/5, olturup ér-di 68a/6, kil-tür-üp ér-diler $64 \mathrm{~b} / 5$, eşit-ip-ér-di-ler $62 \mathrm{~b} / 4$

\section{Görülen Geçmiş Zamanın Hikâyesi}

\section{Geniş Zamanın Hikâyesi}

-r ér, -ur ér-: oku-r ér-di-ler 76a/6-76b/1, ḳl-ur ér-di-ler 68a/4-5, bol-ur ér-di 66a/5-6

\section{Rivayet Birleşik Çekimi}

\section{Öğrenilen Geçmiş Zamanın Rivayeti}

-gan ér-: tap-ġan ér-miş-ler 74b/6-75a/1

\section{Geniş Zamanın Rivayeti}

-r ér-: dir ér-miş-ler $57 \mathrm{~b} / 2-3$

\section{Şart Birleşik Çekimi}

\section{Görülen Geçmiş Zamanın Şartı}

-di érse: dé-di-m érse 57a/4, k11-d1-lar érse 63a/1

\section{Geniş Zamanın Şartı}

\section{Fillerde Olumsuzluk}

-ma-, -me-: tebre-t-al-ma-dı 70b/2-3, oḳu-y-al-ma-sa 78b/3-4, k1l-ma-y-dur 66a/4, kal-ma-gay 62a/5, ögür$m e-\eta 72 \mathrm{~b} / 3$

\section{Fiillerde Soru}

\section{Ek-Fiiller}

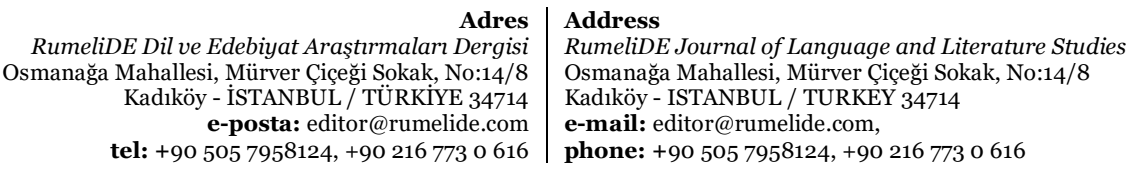


é-: bar-é-ken+dür-ler 69a/4-5

bol-: haşr bolurlar 56a/1-2

ér-: bar ér-di-ler 69a/3, bar ér-miş+ler 57b/1-2, beytü'l-maḳdás ér-di 76a/5-6, bu ér-di 75a/1-2, keşf ér-di-ler 69/4, leşker ér-diler 68a/3, köp ér-di 69a/3-4, țagaları ér-di-ler 73b/6-74a/1

kitltür-: iltica kiltürdiler 70b/4-5

tur-: bul tur-ur 57b/1, fażileti tur-ur 54b/2, étegide tur-ur $67 \mathrm{~b} / 5$

\section{Birleşik Fiiller}

\section{İki Fiilden Oluşan Birleşik Fiiller}

\section{Yeterlilik Fiilleri}

-al-: oḳu-y-al-ma-sa 78b/3-4, tebre-t-al-madı 7ob/2-3

\section{Süreklilik Fiilleri}

-a-: bar-a-dur 61a/4-5, k1l-a-dur 66a/3, ayt-a-kir-in 68b/1-2

\section{Kuvvetlendirme ve İhtimal/Bildirme Eki}

-dir, +dur, +dür: eşit-ip-dir-ler 56a/3-4, ayt-kan+lar+ıpız+dur+miz 72b/4, bar+dur 55b/2, bul+dur 75a/56, hak+dur 74b/4, nûr+dur 61a/6-61b/1, koy-up-dur-lar 68b/3-4, ohşa-p-dur 61a/5-6, köp+dür 57a/6, şehr+dür $55 \mathrm{~b} / 4$

-dü: $\quad$ kil-tür-üp-dü-ler $65 \mathrm{~b} / 1$

Morfolojik olarak eser incelendiğinde klasik dönem ve kalsik sonrası Çağatayca özelliklerini yansıttığını görmekteyiz. Mesela, yazmada birden çok heceli isimlerin sonunda yer alan "G" sesi varlığını korumaktadır ( $u l u+\dot{g}$ 70a/6). ET topluluk sayıları yapan +AgU(n) eki (Tekin, 2016: 123) klasik sonrası Çağataycada + Av şeklindedir (ék+ev+len 71b/2). El yazmasında görülen ve üzerinde durulması gereken bazı morfolojik hususiyetler şunlardır:

-Alek (koy-a+lek 70a/4-5) zarf fiil ekinin kullanılması. Çağatayca kaynaklarda böyle bir zarf fiil ekine rastlanmamaktadır. Ekin Kırgız Türkçesinde özgü olduğunu belirten Çengel ilgili eke gelecek zaman bildiren sıfat fiiller arasında yer vermiştir (Çengel, 2005: 301). S. Tolkun ise bazı sıfat fiil ekleri gibi hâl ekleri ile birleşerek zarf fiil görevi üstlendiğine pek rastlanmamakla birlikte nadiren de olsa zarf fiil olarak kullanıldığını vurgulamaktadır (Tolkun, 2006: 173).

Çağataycada "sor-" fiili daha yaygın olarak kullanılmaktayken metinde günümüz Kırgız Türkçesinde de kullanılmakta olan "sura (sora)-" fiili kullanılmıştır ve bu fiil "sur-a-" biçimindedir (Oruzbayeva, 2000: 269).

Çağataycada çokluk eki “-lAr"dır (Eckmann, 2009: 65). Bununla birlikte Türk dillerinde işteş eylem de çokluk bildirir, Kırgız Türkçesinde olduğu gibi bazen de çokluk eki olarak kullanılabilir. Metinde bu ekin

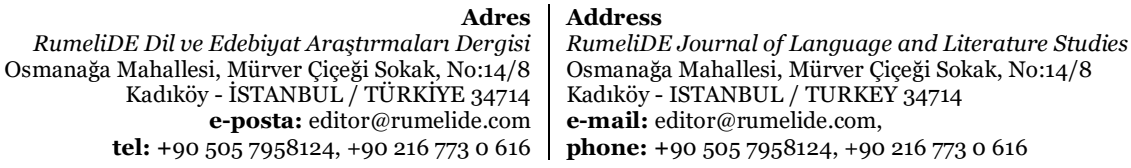


bir yerde işteş eylem görevinden daha ziyade çokluk eki olarak kullanıldığı görülmektedir. al-1ş-1p $75 \mathrm{a} / 3$

Çağataycada zamir “n”'si bulunmamaktadır. Oysa bazı kelimelerde Oğuzca etkisiyle zamir “n”'si görülür. tününde, gününde, boynundan (Kara 1998: 133). El yazmasında iki kullanım bulunmaktadır.

ET'de -(I)g olan belirtme durumu eki Oğuzcada "g" erimsi ile "I" hâlini almıştır (Korkmaz 1972: 441). Çağataycada bu ek "-nI" iken bazen "-I" olması Oğuzca etkisiyledir (Kaymaz 2004: 205). El yazmasında barça+lar+159b/3, kişi+yi 78a/6 gibi örneklerde bu eke rastlanmaktadır.

Çağataycada yönelme durumunda “-GA” iken Çağatayca pek çok metinde olduğu gibi Oğuzca etkisiyle “-A” da görülmektedir. El yazmasında Oğuzca yönelme durumu eki olan “-A” bir örnekte -e olarak görülmektedir. ziyāret+e $74 \mathrm{~b} / 5$

Çağataycada -GAn, -Kan olan sıfat fiil ekleri yerine, Oğuzcanın etkisiyle -An sıfat fiil eki de bazı metinlerde görülebilir (Eker 2012: 72, Kaymaz 2002: 156). El yazmasında ér-en+ler 77a/2 sözcüğünde bu ek görülmektedir. Bununla birlikte EAT'sinde de az da olsa -ġan/-gen eki görülmektedir (Korkmaz 1995: 252).

\section{Sonuç}

Türk İslam edebiyatında çok geniş bir yazım alanı olan ve belli bir yazım şekli bulunmayan faziletnâmelerden bir kısmı şehirleri tanıtmaktadır. Bu şehirler daha çok İslam tarihinde önemli yeri olanlardır. Kırgızistan'ın güneybatısında yer almakta olan Oş şehri hakkında da böyle bir Çağatayca el yazması bulunmaktadır ve eser Risale-yi Hayru'l-Buldan olarak adlandırılmıştır. Eserin yazarı belli olmakla beraber yazıldığı tarih, yer hakkında elimizde bilgi bulunmamaktadır.

Ses bilgisi bakımından metin incelendiğinde eserin Çağataycanın genel hususiyetlerini taşıdığı; ancak bu dönemde oluşmuş olan bazı ses olaylarının metinde bulunmadığı görülmektedir (t>d: taḳ $58 \mathrm{~b} / 1$, tag 66b/2). ET "sub" Çağataycada "suv" olmuş iken metinde bir yerde "suy" şeklinde bulunmaktadır. Yazmada Oğuzca unsur olan yuvarlaklaşmaya da rastlanmaktadır. ilgerü 60a/1, éşittük 60a/1-2, tuymas $u$ nlar $63 \mathrm{~b} / 1 \mathrm{vb}$.

Zamir n'sinin kullanılması, belirtme dururumu eki olarak "I"nın da kullanılması, yönelme durumu eki olarak "-GA" yanı sıra “-e"nin de kullanılması, sıfat fiil eki olarak “-GAn” yanı sıra “-en”in de bulunması metindeki Oğuzca unsurlardır.

"sor-" fiili yerine, günümüz Kırgız Türkçesinde de kullanılmakta olan "sura-" filinin kullanılması, günümüz Kırgızcasında olduğu gibi "-1ş” işteşlik ekinin çokluk eki olarak kullanılması ve yine Kırgızca bir hususiyet olan "-Alek” zarf fiilin kullanılması göz önünde bulundurulduğunda ve metnin yazıldığı coğrafya dikkate alındığında metnin yazarı veya müstensihinin Kırgızca bilen bir kişi olma ihtimali yüksektir.

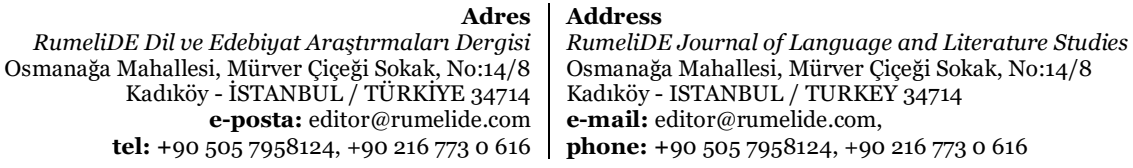


318 / RumeliDE Journal of Language and Literature Studies 2022.26 (February)

Hayru'l-Buldan (Osh) Tractate (translation writing, phonetics, morphology) / R. Yürümez \& Ü. Aldemir (pp. 300-321)

\section{Tipkıbasım örneği}
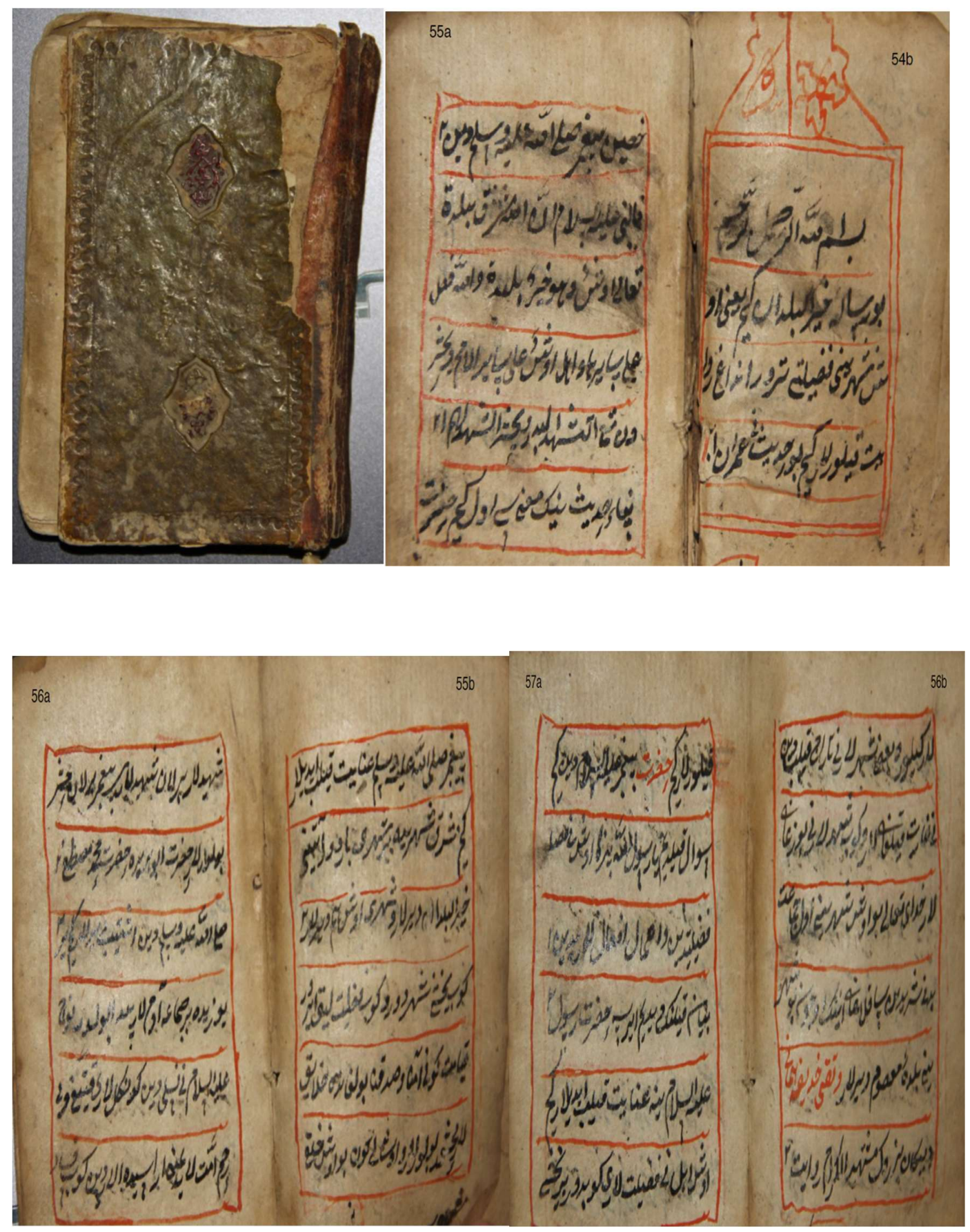

Adres | Address

RumeliDE Dil ve Edebiyat Araştırmaları Dergisi $\quad$ RumeliDE Journal of Language and Literature Studies Osmanağa Mahallesi, Mürver Çiçeği Sokak, No:14/8 Kadıköy - İSTANBUL / TÜRKIYE 34714

e-posta: editor@rumelide.com

Osmanağa Mahallesi, Mürver Çiçeği Sokak, No:14/8

Kadıköy - ISTANBUL / TURKEY 34714

e-mail: editor@rumelide.com,

tel: +90 505 7958124, +90 2167730616 phone: +90 505 7958124, +90 2167730616 

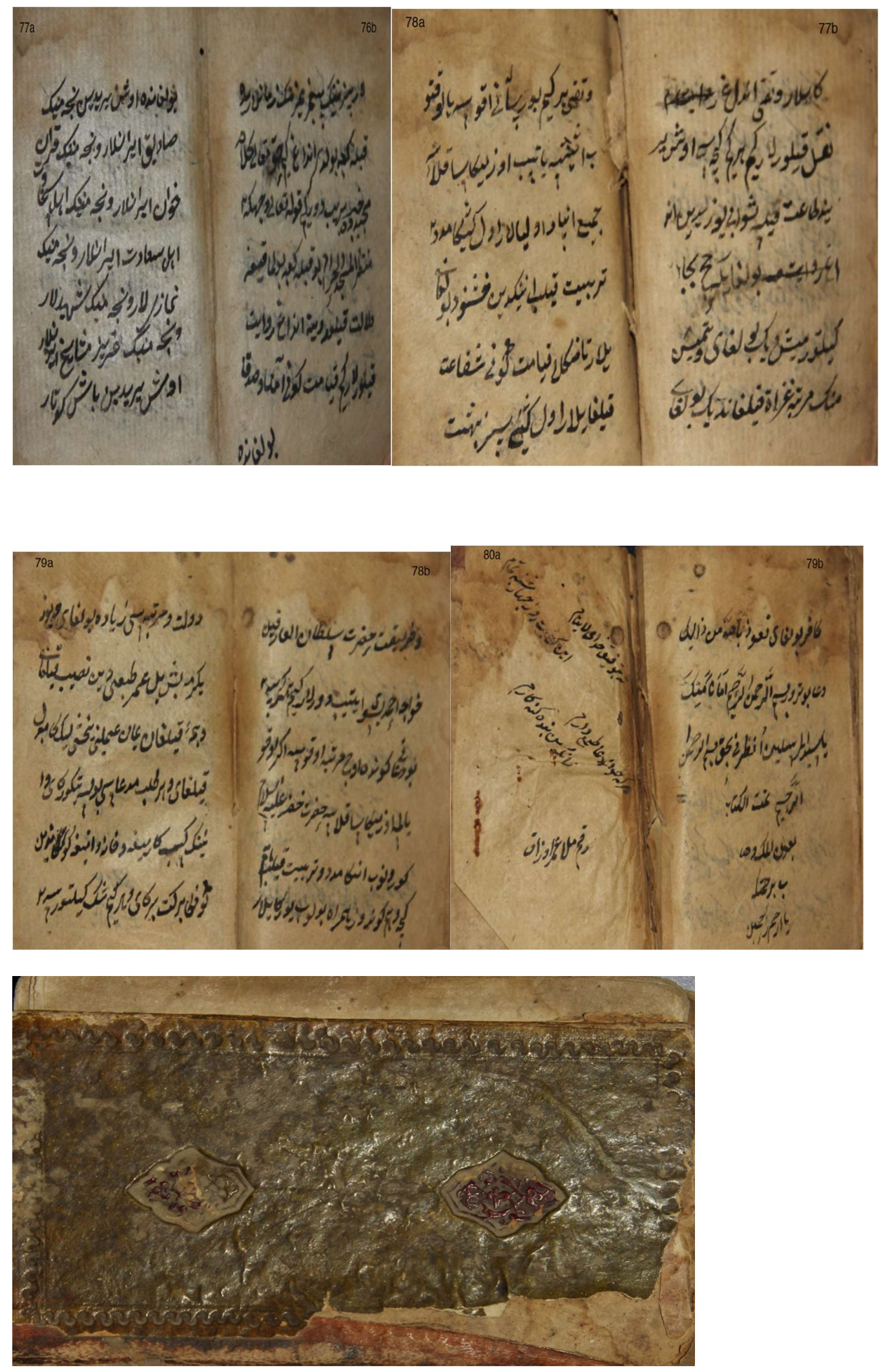

Adres | Address

RumeliDE Dil ve Edebiyat Araştırmaları Dergisi $\quad$ RumeliDE Journal of Language and Literature Studies Osmanağa Mahallesi, Mürver Çiçeği Sokak, No:14/8 $\quad$ Osmanağa Mahallesi, Mürver Çiçeği Sokak, No:14/8 Kadıköy - ISTANBUL / TÜRKIYE 34714 Kadıköy - ISTANBUL / TURKEY 34714

e-posta: editor@rumelide.com $\quad$ e-mail: editor@rumelide.com,

tel: +90 505 7958124, +902167730616 1 phone: +90 505 7958124, +902167730616 


\section{Kaynakça}

Argunşah, M. (2018). Çağatay Türkçesi. Kesit, İstanbul.

Brudnıy, D,. Eşmambet, K., (2017). Kırgız Masalları ve Efsaneleri. (Çev. Buyar, C., Ragibova, İ.). Bilge Kültür Sanat, İstanbul.

Buyar, C., (2019). İpek Yolu Üzerinde Tarihî Bir Şehir: Oş. Kırgızistan Araştırmaları 2019, BYR Publıshıng House, Bişkek.

Cumagulov, Ç., (2001). Oş Şehrinin Epigrafik Anıtları. Atatürk Kültür Merkezi Başkanlığı Yayınları, Ankara.

Çelik, F., (2020). Kırgızca ve Güney Sibirya Türk Lehçelerinde Ses Uyumunun Tipolojisi. Uluslararası Beşeri Bilimler ve Eğitim Dergisi, Cilt 6, Sayı 14, ss. 470-490.

Çengel, H. (2005). Kırgız Türkçesi Grameri. Akçă̆, Ankara.

Eckmann, J. (2009). Çağatayca El Kitabı. (Çev. Günay Karaağaç). Kesit, İstanbul.

Eker, Ü., (2012). Seyyid Kasımî’nin Destanlarında Görülen Eski Anadolu Türkçesi Etkisi. Bozok Üniversitesi İlahiyat fakültesi, 2,2, ss. 63-84.

Güzeldir, M. (2002). Abuşḳa Lügati (Girşiş, Metin, İndeks). Atatürk Üniversitesi Sosyal Bilimler Enstitüsü Türk Dili ve Edebiyatı Ana Bilim Dalı, Doktora Tezi, Erzurum.

Kara, M., (1998). Mahtumkulu'nun Şiirlerinde Çağatayca ve Oğuzca Unsurlar. Bilig / 7 Güz, Ankara, ss. 131-135.

Kaymaz, Z., (2002). Hoca Ahmet Yesevî’nin Hikmetlerindeki Oğuz Türkçesi Unsurları. Türk Dünyası Araştırmaları, Sayı 139, Ağustos, İstanbul, ss. 155-162.

Kaymaz, Z., (2004). Çağatay Türkçesinde Oğuzca Unsurlar Üzerine. Amancolovskie çteniya, Öskemen, Kazakistan, ss. 204-210.

Korkmaz, Z., (1972). Eski Türkçedeki Oğuzca Belirtiler. Bilimsel Bildiriler, TDK, Ankara, ss. 433-446.

Korkmaz, Z., (1995). Kâşgarlı Mahmud ve Oğuz Türkçesi. Türk Dili Üzerine Araştırmalar, C.1, TDK, Yay. 629, Ankara, ss. 241-253.

Risbaev, S., Batırkulova, A., Uraimov, K., İbragimov, K., Mukambetova, A., Madumarov, M., (2016). AlaToo Ulamışları. Biyiktik Plyus. 2. Cilt, Bişkek.

Tekin, T., (2016). Orhon Türkçesi Grameri. TDK Yayınları, Ankara.

Tolkun, S. (2006). Kırgız Türkçesinde -A elek Partisibi (Diğer Türk Lehçelerinde Görülmeyen Tipik Bir Sıfat-Fiil Eki). KTMÜ Sosyal Bilimler Dergisi, Sayı 15, Bişkek, ss. 167-176.

Ünal, İ,H,. (2000). Sehirlerin Faziletiyle İlgili Uydurma Hadisler Ve "Hayru'l-Buldan" Risalesi. Ankara Üniversitesi İlahiyat Fakültesi Dergisi, 41 (1), ss. 67-90.

Ünlü, S,. (2013). Çağatay Türkçesi Sözlüğü. Eğitim Yayınevi, Konya.

Yıldırım, A., \& S,ims, ek, H. (2008). Sosyal Bilimlerde Nitel Aras,tırma Yöntemleri (6.Baskı). Ankara: Sec,kin Yayıncılık.

Yılmaz, K., (2017). Türk İslam Edebiyatında Faziletnameler ve Mekke, Medine, Kudüs, Şam Üzerine Yazılmış Manzum Bir Faziletname. Bilecik Şeyh Edebali Üniversitesi Sosyal Bilimler Enstitüsü Dergisi, Cilt 2, Bilecik, ss. 366-381.

Yürümez, R. (2020). Çağatay Şairi Harâbâtî’nin Fakr-Namesi (İnceleme, Çeviriyazı, Dizin, Ek Dizin, Tıpkıbasım). Kırgızistan-Türkiye Manas Üniversitesi Sosyal Bilimler Enstitüsü Türkoloji Anabilim Dalı, Bişkek.

\section{İnernet adresleri}

URL1: https://runivers.ru/doc/historical-journal/article/?JOURNAL=\&ID=479416 (15.11.2021)

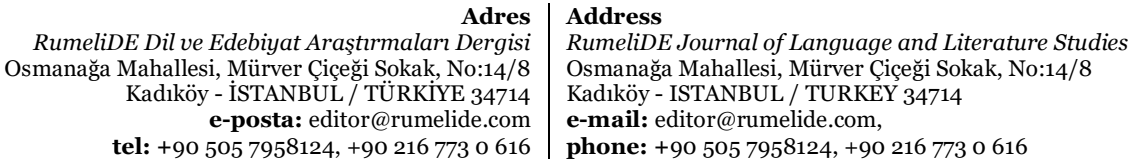

RumeliDE Dil ve Edebiyat Araştırmaları Dergis Kadiköy - ISTANBUL / TÜRKIYE 34714 tel: +90 $5057958124,+902167730616$

ditor@rumelide.com,

phone: +90 505 7958124, +90 2167730616 
URL2: stat.kg (08.11.2021)

URL3: Erdoğan Akkan, "Kirgizistan", TDV İslâm Ansiklopedisi, https://islamansiklopedisi.org.tr/kirgizistan\#1 (08.11.2021). 